\title{
Review of Nomads in Postrevolutionary Iran: The Qashqa'i in an Era of Change by Lois Beck
}

\author{
Richard Tapper(1)
}

\author{
Book details: Lois Beck \\ Nomads in Postrevolutionary Iran: The Qashaa'i in an Era of Change \\ Abingdon: Routledge, 2015 \\ xxv, 404 pages \\ Hardcover: ISBN: 978-1-138-01561-6; ISBN: 978-1-315-79422-8; Paperback: ISBN: 978-1-138-09972-2
}

Keywords: Iran, Islamic Republic, Qashqa'i, Nomadic peoples, Tribe-state relations

The Qashqa'i are one of Iran's largest and most important nomadic tribal peoples, along with the Bakhtiari (familiar from the classic documentaries Grass and People of the Wind). They have been the subjects of several academic studies, as well as popular novels such as Vincent Cronin's (1957) The Last Migration, and films such as Mohsen Makhmalbaf's Gabbeh.

In the past, the Qashqa'i - among the Turki-speaking minority, but Shi'a Muslims like the majority - have played an important political role in Iran. After the revolution of 1978 to 1979, the Qashqa'i khans, once powerful enemies of the Pahlavi regime, were the only major tribal chiefs to attempt (unsuccessfully) to regain their position. Today, the government and the settled and non-tribal Persian-speaking majority continue to regard Qashqa'i nomads with ambivalence: as both relics of a primitive and dangerous past, and colourful and exotic attractions for Iranian and foreign tourists.

Anthropologist Lois Beck has been the Qashqai's most assiduous and prolific chronicler. For half a century, she has regularly visited and lived with Qermezi, a subtribe (numbering a few hundred families) of the Darrashuri, one of five major Qashqa'i component tribes. This longterm commitment is unparalleled for a foreign ethnographer in Iran. Nomads in Postrevolutionary Iran is Beck's third Qashqa'i monograph, following The Qashqa'i of Iran (Beck 1986), a historical-political

Correspondence: rt3@soas.ac.uk

SOAS University of London, London, United Kingdom ethnography, and Nomad: A Year in the Life of a Qashqa'i Tribesman in Iran (Beck 1991). Beck's daughter Julia Huang accompanied her to Iran from the age of five, and in effect grew up as a Qashqa'i; she has since become a qualified anthropologist and contributed a further excellent, and complementary, monograph of her own: Tribeswomen of Iran: Weaving Memories among Qashqa'i Nomads (Huang 2009).

Anthropologists traditionally fall into one of two categories. Some, from choice or circumstance, over their careers have conducted major ethnographic field studies in two or more unrelated contexts. A renowned example was the late Fredrik Barth, one of whose earliest ethnographic subjects was the Basseri tribe, neighbours of the Qashqa'i. The present reviewer has revisited and kept in touch with some of his own first field subjects the Shahsevan, another Turki-speaking nomadic tribal people in Iran - over half a century, but chose for personal and political reasons to pursue later research in neighbouring countries, becoming acutely aware of the anthropological advantages and disadvantages of this career choice.

Others, like Beck, have devoted their careers to living with and studying a single people, even a single small community. Such commitment sometimes leads to accusations of a form of 'ethnocentrism': seeing the world (and building theories and generalizations) through the eyes of 'their' fieldwork subjects. Beck, however, has always situated her own detailed ethnographic narratives and analyses in wider contexts and has been careful to 
avoid unwarranted generalizations about Iranian nomadic and tribal peoples, or about Iran generally, based solely on her experience among the Qashqa'i - though the main title of her latest monograph might suggest otherwise.

Barth's Basseri (1961) study, Nomads of South Persia, based on only six months in the region, achieved the status of a classic among non-Iranian anthropologists and was soon translated into Persian. Numerous European and American student textbooks have treated the Basseri as prototypical - though often the only example mentioned - of nomadic tribes not just of Iran but sometimes of all southwest Asia, despite Barth himself having written monographs about two other, very different, tribal peoples of the region: the Jaf Kurds of Iraq and the Marri Baluch of Pakistan. Of course, there are many similarities between Basseri, Jaf Kurds, Marri Baluch and Qashqa'i, but there are huge cultural, political, economic and other differences, explainable in terms of ecology, scale, history and other factors. A basic feature of Barth's analysis (ignored or played down by many readers) is his distinction between the organizational level of nomadic camps and sub-tribal communities, which are economicecological adaptations to the local demands of pastoralism, and the political level of tribes, confederacies and chiefs, geared to relations with local and state-level government. The relevance of this distinction has become clearer under the Islamic Republic, who recognize and support only the pastoral communities of the former level. This is a central theme running through Nomads in Postrevolutionary Iran.

The title begs the questions who are the 'nomads' and whether (and in what circumstances) the Qashqa'i considered themselves to be 'nomads', rather than 'tribespeople' or 'pastoralists'. The semantic uncertainty and ambiguity is compounded in the Iranian context by official and colloquial terminologies for peoples such as the Qashqa'i. Iranian historians and officials always assumed wrongly that all pastoralists were nomadic and politically organized in tribes (with chiefs) and similarly that all tribes were pastoral nomads, and they were officially referred to as ilat-o-'ashayer. Both component terms (the former of Turkish, the latter of Arabic derivation) denoted 'tribes' (in a political sense) and only secondly 'pastoralists' or 'nomads'. Recently, with the formal suppression, if not abolition, of 'tribes' and 'tribal organization' by the Pahlavis (completed by the Islamic Republic), ilat has been replaced by 'ashayer, which are now explicitly defined as nomadic or semi-nomadic pastoralists, commonly forming groups based on common ancestry, but with no hint of chiefs or tribal political organization.

In a long chapter on government-tribe relations since the revolution, Beck writes interestingly about these semantic changes and their implication among the Qashqa'i, throwing light on official and local usages. After the revolution, with the Iranian government's more positive attitude to minorities, and to pastoral nomads in particular, there were (as in many countries recently) material advantages to being able to claim 'nomad' ('ashayer) identity. For example, paradoxically, as she shows in a later chapter, educated Qermezi who were already settled as schoolteachers in a nearby town, if they kept a few animals grazing under a kinsman's charge on traditional pastures, were able to claim the 'nomad' identity that qualified them for the right, and accompanying subsidies, to build houses and start farming in a 'settlement' on those pasturelands.

Nomads in Postrevolutionary Iran offers the reader little of general theoretical interest (e.g. on tribe-state relations) and not very much on nomadism or pastoralism per se. Despite the title and subtitle, these matters are not Beck's concern here; she has covered them at length and in detail in earlier books and articles. The book is intended as a chronicle of the recent history of the Qermezi subtribe. Borzu, the eponymous subject of her second book Nomad, died in 1995, and Beck dedicates this one to 'Borzu Qermezi, the Qermezi tribal group, the Qashqa'i people'. As Julia Huang writes in her brief but moving Foreword, 'Moved by Borzu's death, my mother wrote Nomads in Postrevolutionary Iran as a tribute to the man and the tribe he represented and loved.' As such, the book sometimes verges on a hagiography, not only of Borzu but also of the Qermezi and the Qashqa'i, and other significant individuals such as Mohammad Bahmanbegi, the founder of Iran's 'tribal' schools. Sometime, it seems to be addressed chiefly to those who have either lived the nomadic life of the Qashqa'i or at least read the author's previous publications on that life. In her Preface, Beck excuses the total absence of maps and diagrams in this book by noting that they are plentiful in the two previous ones.

But the chronicle, presented in a series of chapters of varied length, is complex and highly informative. Nomads in Postrevolutionary Iran is an outstanding micro-historical ethnography. There is little specific discussion of traditional forms of nomadism or pastoralism, and many readers will find that there are passages that can be skimmed, but students of pastoralism will find much of interest and will learn much about how a proud pastoral tribal people cope with the changing demands of participation in a modern state, how current and former nomadic pastoralists seek to adapt to rapidly changing economic and political conditions, taking advantage of new opportunities while maintaining a foot in the nomad camp, wherever it is possible, prudent and profitable to do so. There is much, too, on non-pastoral activities and adaptations, education, housing, 
employment, and participation in political affairs of the Islamic Republic. And we are offered a wealth of detailed and revealing narratives of incidents and encounters: 'martyrs' killed in the Iran-Iraq war; confrontations with puritanical 'Hezbollahi' extremists; the workings of the Islamic Republic's Organization for Nomads' Affairs; Borzu's illness, death and the aftermath; weddings and other ceremonies; and land disputes with encroaching 'Persian' farmers.

Even a reader familiar with Iran and its recent history will gain an enhanced understanding of postrevolutionary Iran by learning about the concerns and fortunes of some of those who live far from the centres that have occupied the attention of most journalists and academic researchers.

Authors' contributions

The author read and approved the final manuscript.

Competing interests

The author declares that he has no competing interests.

\section{Publisher's Note}

Springer Nature remains neutral with regard to jurisdictional claims in published maps and institutional affiliations.

Received: 29 January 2018 Accepted: 30 January 2018

Published online: 27 March 2018

\section{References}

Barth, Fredrik, 1961. Nomads of South Persia: The Basseri tribe of the Khamseh confederacy. London: George Allen \& Unwin, Oslo University Press.

Beck, Lois, 1986. The Qashaa'i of Iran. New Haven: Yale University Press.

Beck, Lois, 1991. Nomad: A year in the life of a Qashqa'i Tribesman in Iran. Berkeley: University of California Press.

Cronin, Vincent, 1957. The Last Migration. London: Rupert Hart-Davis.

Huang, Julia, 2009. Tribeswomen of Iran: Weaving memories among Qashaa'i nomads. London: I B Tauris.

\section{Submit your manuscript to a SpringerOpen ${ }^{\mathcal{O}}$ journal and benefit from:}

- Convenient online submission

- Rigorous peer review

- Open access: articles freely available online

- High visibility within the field

- Retaining the copyright to your article

Submit your next manuscript at $>$ springeropen.com 